\title{
Fabrication and Photovoltaic Characteristics of Coaxial Silicon Nanowire Solar Cells Prepared by Wet Chemical Etching
}

\author{
Chien-Wei Liu, ${ }^{1}$ Chin-Lung Cheng, ${ }^{2}$ Bau-Tong Dai, ${ }^{3}$ Chi-Han Yang, ${ }^{4}$ and Jun-Yuan Wang ${ }^{4}$ \\ ${ }^{1}$ Department of Mechanical Engineering, National Yunlin University of Science and Technology, Yunlin 64054, Taiwan \\ ${ }^{2}$ Department of Electro-Optical Engineering, National Formosa University, Yunlin 63201, Taiwan \\ ${ }^{3}$ National Nano Device Laboratories, National Applied Research Laboratories, Hsinchu 30078, Taiwan \\ ${ }^{4}$ Institute of Materials Science and Green Energy Engineering, National Formosa University, Yunlin 63201, Taiwan \\ Correspondence should be addressed to Chin-Lung Cheng, chengcl@nfu.edu.tw
}

Received 12 October 2011; Revised 12 January 2012; Accepted 20 January 2012

Academic Editor: Gion Calzaferri

Copyright (๑) 2012 Chien-Wei Liu et al. This is an open access article distributed under the Creative Commons Attribution License, which permits unrestricted use, distribution, and reproduction in any medium, provided the original work is properly cited.

Nanostructured solar cells with coaxial p-n junction structures have strong potential to enhance the performances of the siliconbased solar cells. This study demonstrates a radial junction silicon nanowire (RJSNW) solar cell that was fabricated simply and at low cost using wet chemical etching. Experimental results reveal that the reflectance of the silicon nanowires (SNWs) declines as their length increases. The excellent light trapping was mainly associated with high aspect ratio of the SNW arrays. A conversion efficiency of $\sim 7.1 \%$ and an external quantum efficiency of $\sim 64.6 \%$ at $700 \mathrm{~nm}$ were demonstrated. Control of etching time and diffusion conditions holds great promise for the development of future RJSNW solar cells. Improving the electrode/RJSNW contact will promote the collection of carries in coaxial core-shell SNW array solar cells.

\section{Introduction}

Nanostructured solar cells with high efficiency and low cost are being considered to meet the urgent need for third-generation solar cell applications. Recent studies have shown that silicon nanowires (SNWs) that are prepared by the vapor-liquid-solid (bottom up) and wet chemical etching approaches (top down) can be employed to enhance the photovoltaic characterization because such SNW arrays have very low reflectance [1-12]. Theoretical studies have indicated that coaxial SNW structures with sub-5 nm p-n junction structures have potentiality to realize ultrahigh efficiencies due to the tunable energy bandgap [13]. Moreover, the cause of the conversion efficiency improvement can be attributed to the short collection length in radial $p-n$ junction SNW [14]. The properties of SNWs are determined by the enhanced surface area to volume ratio. Theoretical calculations have also predicted that a direct energy bandgap exists in the $4.5-5.3 \mathrm{~nm}$ range for SNWs that are oriented in the $\langle 111\rangle$ direction [15]. The bandgap increases as the diameters of the SNWs decrease in the $7-1.3 \mathrm{~nm}$ range [16]. Accordingly, SNW solar cells are promising for their scalability as nanostructured solar cells. However, the conversion efficiencies (CEs) of SNW solar cells are not yet large enough. SNW solar cells on metal foil with a current density of $1.6 \mathrm{~mA} / \mathrm{cm}^{2}$, an external quantum efficiency (EQE) of $12 \%$ at $690 \mathrm{~nm}$, and a conversion efficiency of $0.1 \%$ have been described [5]. Individual core-shell SNW photovoltaic elements with an opencircuit voltage $\left(V_{\mathrm{oc}}\right)$ of $260 \mathrm{mV}$, a short-circuit current $\left(I_{\mathrm{sc}}\right)$ of $0.503 \mathrm{nA}$, and a fill factor (FF) of $55.0 \%$ have been demonstrated [6]. Radial junction SNW (RJSNW) solar cells with a $V_{\mathrm{oc}}$ of $290 \mathrm{mV}$, a short-circuit current density $\left(J_{\mathrm{sc}}\right)$ of $4.28 \mathrm{~mA} / \mathrm{cm}^{2}$, and an FF of $33.0 \%$ have also been demonstrated [7]. Electrolessly etched SNW solar cells with a $J_{\text {sc }}$ of $1.36 \mathrm{~mA} / \mathrm{cm}^{2}$ and a $V_{\text {oc }}$ of $730 \pm 20 \mathrm{mV}$ have been proposed [17]. Moreover, a lot of SNWs fabricated by metal-assisted chemical etching have demonstrated their application potentials [18-21]. Thus, this study will scrutinize the etching time and the diffusion conditions of RJSNWs.

\section{Experimental Methods}

Square samples with an area of $4 \mathrm{~cm}^{2}$ were cut from (100)-oriented p-type silicon $[\mathrm{p}-\mathrm{Si}(100)]$ wafer with 
TABle 1: Various $\mathrm{AgNO}_{3}$ and $\mathrm{HF}$ concentrations in $\mathrm{AgNO}_{3} / \mathrm{HF} / \mathrm{H}_{2} \mathrm{O}$ mixture chemical solutions, as well as etching time, were employed to explore various surface morphologies of SNWs formed on the p-type $\mathrm{Si}(100)$ substrate.

\begin{tabular}{ccc}
\hline Sample split & $\mathrm{AgNO}_{3} / \mathrm{HF} / \mathrm{H}_{2} \mathrm{O}$ (volume) & Etching time $(\mathrm{min})$ \\
\hline S1 & $2: 34: 164$ & 10 \\
S2 & $4: 34: 162$ & 10 \\
S3 & $6: 34: 160$ & 10 \\
S4 & $8: 34: 158$ & 10 \\
S5 & $4: 31: 165$ & 10 \\
S6 & $4: 38: 158$ & 10 \\
S7 & $4: 41.5: 154.5$ & 10 \\
S8 & $4: 34: 162$ & 1.5 \\
S9 & $4: 34: 162$ & 3 \\
S10 & $4: 34: 162$ & 30 \\
\hline
\end{tabular}

$\rho=0.5-3 \Omega \mathrm{cm}$. The thicknesses of all p-Si (100) wafers were approximately $210 \pm 30 \mu \mathrm{m}$. All samples were firstly cleaned by a wet cleaning process (APM/HPM/DHF), using an $\mathrm{NH}_{4} \mathrm{OH} / \mathrm{H}_{2} \mathrm{O}_{2} / \mathrm{H}_{2} \mathrm{O}$ mixture $(\mathrm{APM})$ in a ratio of $1: 4: 20$ (volume) at $75^{\circ} \mathrm{C}$ and an $\mathrm{HCl} / \mathrm{H}_{2} \mathrm{O}_{2} / \mathrm{H}_{2} \mathrm{O}$ mixture (HPM) in a ratio of $1: 1: 6$ (volume) at $75^{\circ} \mathrm{C}$, to remove residues and contaminants. The dipping time in all processes was 10 min. Diluted HF (DHF) with an $\mathrm{HF}: \mathrm{H}_{2} \mathrm{O}$ ratio of $1: 100$ (volume) was used to remove native oxide. Following the wet processes, all of the samples were rinsed in deionized water for $10 \mathrm{~min}$. Then, the square $\mathrm{p}$-Si(100) wafers were immersed in an aqueous $\mathrm{AgNO}_{3} / \mathrm{HF} / \mathrm{H}_{2} \mathrm{O}$ mixture chemical solutions [22]. The detailed process conditions of aqueous $\mathrm{AgNO}_{3} / \mathrm{HF} / \mathrm{H}_{2} \mathrm{O}$ mixture chemical solutions are summarized in Table 1. The concentration of $\mathrm{AgNO}_{3}$ was set to $1 \mathrm{~mol} \mathrm{~L}^{-1}$. Subsequently, all SNW/p-Si(100) structures were etched in nitric acid solution to eliminate the residual $\mathrm{Ag}$ dendrites that were observed on the surface and in between the SNWs. Phosphorosilicafilm $\left(5 \times 10^{20} \mathrm{~cm}^{-3}\right)$ is a dopant formulation designed to produce phosphorous diffused layers in $\mathrm{SNW} / \mathrm{p}-\mathrm{Si}(100)$ structures by spin on coating. Then, the SNW/p-Si(100) structures coated with phosphorosilicafilm were performed by thermal phosphorus diffusion in a quartz tube furnace at $950^{\circ} \mathrm{C}$ in nitrogen ambient for 2.5, 3, 4, and 5 hrs as shown in Table 2. After the phosphorus glass was removed by DHF solution and rinsed in deionized water, the front electrodes of the RJSNWs were deposited by the vacuum sputtering of $\mathrm{Ti}(\sim 30 \mathrm{~nm})$ followed by $\mathrm{Al}(\sim 500 \mathrm{~nm})$ through a metal shadow mask. The rear $\mathrm{Al}(\sim 500 \mathrm{~nm})$ contacts were formed by sputtering. Finally, thermal baking was carried out in $\mathrm{N}_{2} / \mathrm{H}_{2}$ ambient at $450^{\circ} \mathrm{C}$ for $15 \mathrm{~min}$ to improve the quality of the Ohmic contacts. Figure 1 schematically depicts the device structure of an RJSNW solar cell with an area of $4 \mathrm{~cm}^{2}$. All samples were observed using a secondary electron microscope (SEM), an ultraviolet/visible/near infrared spectrometer, and a current-voltage $(I-V)$ measuring device. The $I-V$ characteristics of all solar cells were measured under AM1.5 class 3A illumination source with at $25^{\circ} \mathrm{C}$. Full spectrum solar simulator lamp type is $300 \mathrm{~W}$ Xenon. A profile of phosphorus concen-
TABLE 2: Various etching times of $\mathrm{AgNO}_{3} / \mathrm{HF} / \mathrm{H}_{2} \mathrm{O}$ mixture chemical solutions, as well as diffusion times, were employed to explore the electrical properties of SNWs solar cells.

\begin{tabular}{ccc}
\hline Sample split & $\begin{array}{c}\mathrm{AgNO}_{3} / \mathrm{HF} / \mathrm{H}_{2} \mathrm{O} 4: 34: 162 \\
\text { (volume) Etching time } \\
(\mathrm{min})\end{array}$ & $\begin{array}{c}\text { Diffusion time } \\
(\mathrm{min})\end{array}$ \\
\hline S11 & 1.5 & 2.5 \\
S12 & 1.5 & 3 \\
S13 & 3 & 3 \\
S14 & 30 & 3 \\
S15 & 1.5 & 4 \\
S16 & 1.5 & 5 \\
\hline
\end{tabular}



- A wet cleaning process (APM/HPM/DHF)

- SNWs formation using $\mathrm{AgNO}_{3} / \mathrm{HF} / \mathrm{H}_{2} \mathrm{O}$

- n-type emitter formation using furnace annealing (RJSNWs formation)

- Phosphorus glass removal

- Top/bottom electrode formation

- A thermal baking

FIGURE 1: Schematic structure of radial junction silicon nanowire (RJSNW) solar cell.

tration in the n-type emitter layer was obtained by secondary ion mass spectroscopy (SIMS).

\section{Results and Discussion}

Various $\mathrm{AgNO}_{3}$ and $\mathrm{HF}$ concentrations in $\mathrm{AgNO}_{3} / \mathrm{HF} / \mathrm{H}_{2} \mathrm{O}$ mixture chemical solutions, as well as etching time, were employed to explore various surface morphologies of SNWs formed on the p-type $\mathrm{Si}(100)$ substrate. To observe all of the morphologies of the SNW array structures, plane and oblique SEM images of SNW/p-Si(100) structures were obtained and presented in Figures 2-4. Figure 2 shows various SEM images of various $\mathrm{SNW} / \mathrm{p}-\mathrm{Si}(100)$ structures. Etching conditions were aqueous $\mathrm{AgNO}_{3} / \mathrm{HF} / \mathrm{H}_{2} \mathrm{O}$ mixture chemical solution in a ratio of (a) $2: 34: 164$, (b) $4: 34: 162$, (c) $6: 34: 160$, and (d) $8: 34: 158$ (volume), respectively, at $25^{\circ} \mathrm{C}$ for 10 min. The concentration of $\mathrm{AgNO}_{3}$ in $\mathrm{AgNO}_{3} / \mathrm{HF} / \mathrm{H}_{2} \mathrm{O}$ mixture chemical solution was increased. It can be seen that short SNWs were formed on the p-type $\mathrm{Si}(100)$ substrate resulting from low $\mathrm{AgNO}_{3}$ concentration as shown in Figure 2(a). On the contrary, the long SNWs were demonstrated using high $\mathrm{AgNO}_{3}$ concentration in $\mathrm{AgNO}_{3} / \mathrm{HF} / \mathrm{H}_{2} \mathrm{O}$ mixture chemical solution as shown in Figure 2(d). Thus, the results suggest that the length of SNW increases with 


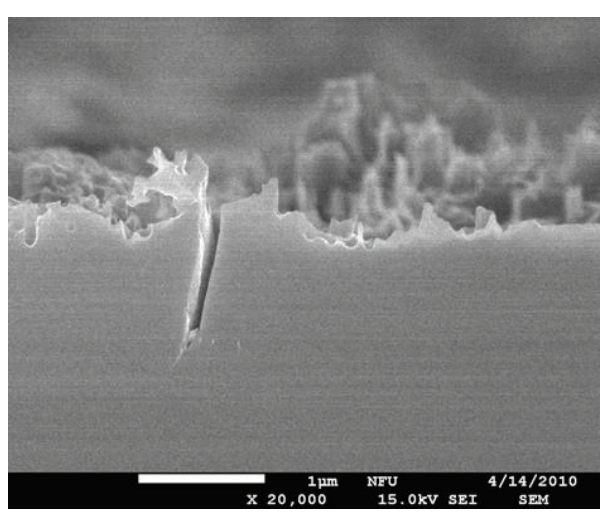

(a)



(c)

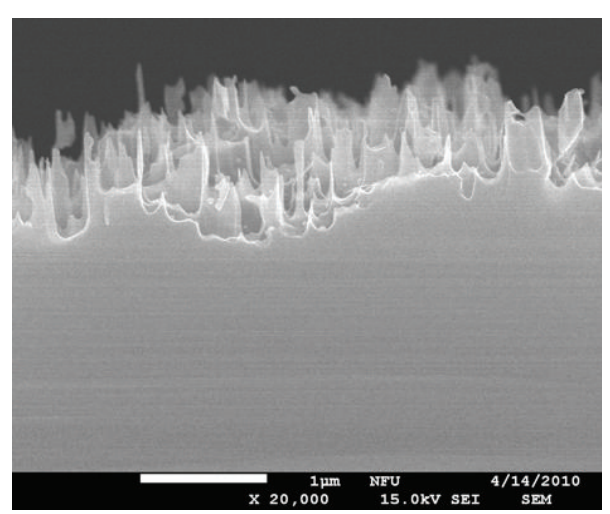

(b)

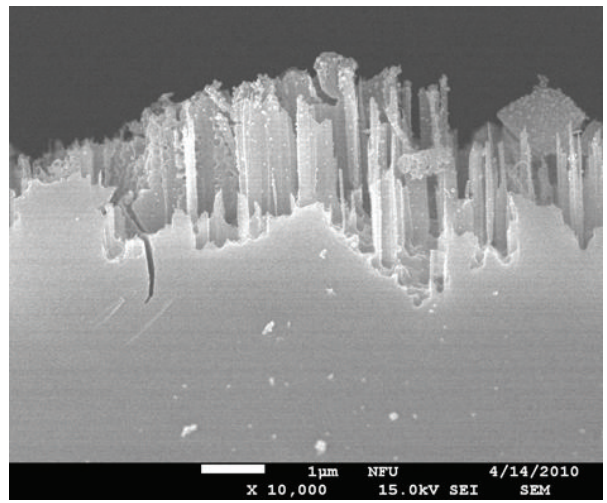

(d)

FIGURE 2: SEM images of various $\mathrm{SNW} / \mathrm{p}$-Si(100) structures. Etching conditions were aqueous $\mathrm{AgNO}_{3} / \mathrm{HF} / \mathrm{H}_{2} \mathrm{O}$ mixture chemical solution in a ratio of (a) $2: 34: 164$, (b) $4: 34: 162$, (c) $6: 34: 160$, and (d) $8: 34: 158$ (volume) at $25^{\circ} \mathrm{C}$ for 10 min. The concentration of $\mathrm{AgNO}_{3}$ was $1 \mathrm{~mol} \mathrm{~L}{ }^{-1}$.

increasing concentration of $\mathrm{AgNO}_{3}$ in $\mathrm{AgNO}_{3} / \mathrm{HF} / \mathrm{H}_{2} \mathrm{O}$ mixture chemical solution.

To realize the effects of $\mathrm{HF}$ concentrations in $\mathrm{AgNO}_{3}$ $/ \mathrm{HF} / \mathrm{H}_{2} \mathrm{O}$ mixture chemical solutions, etching conditions were aqueous $\mathrm{AgNO}_{3} / \mathrm{HF} / \mathrm{H}_{2} \mathrm{O}$ mixture chemical solution in a ratio of (a) $4: 31: 165$, (b) $4: 38: 158$, and (c) $4: 41.5: 154.5$ (volume), respectively, at $25^{\circ} \mathrm{C}$ for $10 \mathrm{~min}$, and presented in Figure 3. Compared with high HF concentration, the short SNWs were formed by $\mathrm{AgNO}_{3} / \mathrm{HF} / \mathrm{H}_{2} \mathrm{O}$ mixture chemical solution with low HF concentration. Therefore, the results indicate that the length of SNWs decreases with decreasing $\mathrm{HF}$ wt $\%$ in $\mathrm{AgNO}_{3} / \mathrm{HF} / \mathrm{H}_{2} \mathrm{O}$ mixture chemical solutions. It has been reported that the $\mathrm{Si}$ atoms are oxidized and dissolved at the interface between the $\mathrm{Ag}$ metal and the $\mathrm{Si}$ substrate and that the reagent and byproduct diffuse along this interface [23]. Thus, the densities and lengths of SNWs increase with increasing $\mathrm{HF}$ and $\mathrm{AgNO}_{3}$ concentration in aqueous $\mathrm{AgNO}_{3} / \mathrm{HF} / \mathrm{H}_{2} \mathrm{O}$ mixture chemical solution.

Figure 4 shows various SEM images of various SNW/p$\mathrm{Si}(100)$ structures. Etching conditions were aqueous $\mathrm{AgNO}_{3} / \mathrm{HF} / \mathrm{H}_{2} \mathrm{O}$ mixture chemical solution in a ratio of $4: 34: 162$ (volume) at $25^{\circ} \mathrm{C}$ for (a) 1.5 , (b) 3 , and (c) $30 \mathrm{~min}$, respectively. The lengths of the SNW arrays ranged from 600 to $10000 \mathrm{~nm}$ and depended critically on the etching time. These results suggest that the densities and the lengths increased with the duration of wet chemical etching. Thus, the SNWs can be obtained by a suitable tuning $\mathrm{AgNO}_{3}$ and $\mathrm{HF}$ concentrations in $\mathrm{AgNO}_{3} / \mathrm{HF} / \mathrm{H}_{2} \mathrm{O}$ mixture chemical solutions.

Figure 5 shows the top morphologies of the SNW/p$\mathrm{Si}(100)$ structure at magnifications of (a) $\times 10 \mathrm{k}$, and (b) $\times 50 \mathrm{k}$. The etching condition was an aqueous $\mathrm{AgNO}_{3} / \mathrm{HF} / \mathrm{H}_{2} \mathrm{O}$ mixture chemical solution with a ratio of $4: 34: 162$ (volume) at $25^{\circ} \mathrm{C}$ for $3 \mathrm{~min}$. The cross-sections of SNW arrays exhibited nonregular morphologies and their sizes ranged from 300 to $1000 \mathrm{~nm}$. The SEM images in Figure 5 also indicate that the surface of SNWs exhibited nanostructured texturization. Research has demonstrated that the nanostructure textured arrays at silicon surfaces prepared by a wet chemical process have low reflection [24]. In this study, SNW arrays with a larger aspect ratio of around $40: 1$ were obtained after an etching time of $30 \mathrm{~min}$. Accordingly, the SNW arrays with various aspect ratios and microstructural arrays will play a main role of the light trapping.

To elucidate the reflectance characteristics of various SNW arrays, reflectance spectra of various SNW/p-Si(100) structures were obtained and shown in Figure 6. An integrating sphere was used to ensure that all reflected light was captured over all angles. The diameter of the integrating sphere was $60 \mathrm{~mm}$. The reflectance spectra confirm that the reflectance of SNW arrays decreases as their lengths 


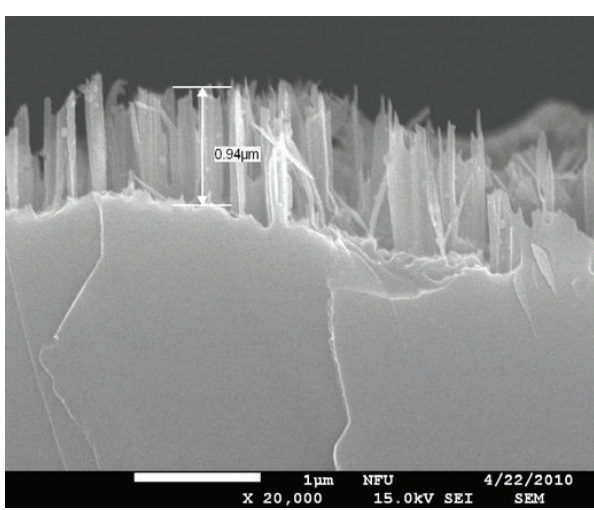

(a)

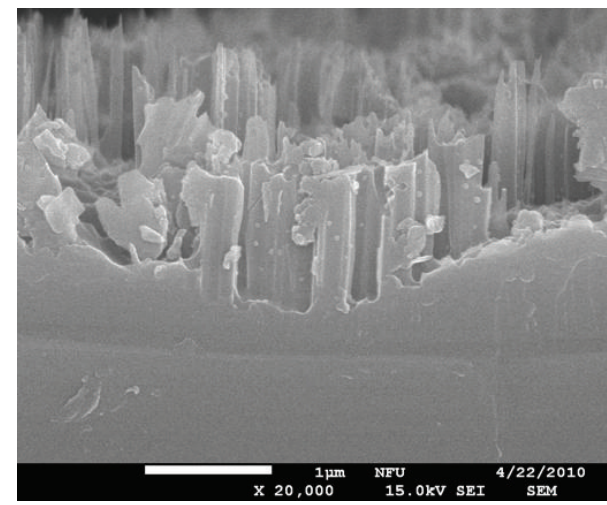

(b)



(c)

Figure 3: SEM images of various SNW/p-Si(100) structures. Etching conditions were aqueous $\mathrm{AgNO}_{3} / \mathrm{HF} / \mathrm{H}_{2} \mathrm{O}$ mixture chemical solution in a ratio of (a) $4: 31: 165$, (b) $4: 38: 158$, and (c) $4: 41.5: 154.5$ (volume) at $25^{\circ} \mathrm{C}$ for $10 \mathrm{~min}$. The concentration of $\mathrm{AgNO}_{3}$ was $1 \mathrm{~mol} \mathrm{~L}^{-1}$.

increase. The excellent trapping of light was mostly associated with the high aspect ratio of the SNW arrays. Figure 6 also shows the reflectance spectrum of planar $\mathrm{p}-\mathrm{Si}(100)$ substrate as a reference. The planar $\mathrm{p}-\mathrm{Si}(100)$ structure had a larger reflectance than SNWs. Hence, SNW arrays with a high aspect ratio can have a very low reflectance, and SNW arrays with low reflectance have potential for use as antireflective coatings (ARCs) of solar cells.
The n-type emitter layer in $\mathrm{p}$-n junction silicon solar cell is usually doped to a level that suffices to conduct away the generated carriers without causing resistive loss. However, excessive levels of doping reduces carrier lifetime to the extent that carriers recombine before reaching the $p-n$ junction. Therefore, the n-type emitter layers of SNW arrays with various diffusion times as shown in Table 2 were utilized to optimize the characteristics of the emitter layer. The n-type SNW/p-Si(100) structures in this investigation were formed by the diffusion of phosphorus at $950^{\circ} \mathrm{C}$ in nitrogen ambient for $3 \mathrm{hrs}$, resulting in an emitter with a depth of approximately $150 \mathrm{~nm}$, as presented in Figure 7. The resistivity of the p-type substrate was $0.5-3 \Omega \mathrm{cm}$, corresponding to a doping density of approximately $5 \times 10^{15} \sim 6 \times 10^{16} \mathrm{~cm}^{-3}$ [25]. The higher phosphorous concentrations in Figure 5 ( $>3$ $\times 10^{16} \mathrm{~cm}^{-3}$ ) were detected when the junction depth lowered $150 \mathrm{~nm}$. Hence, an emitter layer thickness of approximately $150 \mathrm{~nm}$ was extrapolated. A p-type SNW with a cross-section size of smaller than $300 \mathrm{~nm}$ was converted to an n-type SNW by diffusion at $950^{\circ} \mathrm{C}$ in nitrogen ambient for 3 hrs. However, the cross-section sizes of the SNW arrays ranged from 300 to $1000 \mathrm{~nm}$. Most SNWs dimensions were larger than $300 \mathrm{~nm}$, according to their morphologies presented in Figure 5. Thus, most coaxial core-shell-type p-n junction SNWs were demonstrated. The modulation of etching time and diffusion conditions is very promising for the future development of RJSNW solar cells.

Figure 8 plots current density-voltage $(J-V)$ curves of various n-type $\mathrm{SNW} / \mathrm{p}-\mathrm{Si}(100)$ structured solar cells, obtained in the dark and under illumination (AM 1.5). The efficiencies were measured under the global AM1.5 spectrum $\left(1000 \mathrm{~W} / \mathrm{m}^{2}\right)$ at $25^{\circ} \mathrm{C}$. An improved $\mathrm{CE}$ of approximately $7.1 \%$ with a $J_{\mathrm{sc}}$ of $27 \mathrm{~mA} / \mathrm{cm}^{2}$, a $V_{\text {oc }}$ of $500 \mathrm{mV}$, and an FF of $52 \%$ was obtained for an RJSNW array solar cell sample with a diffusion time of 3 hrs. Etching conditions were aqueous $\mathrm{AgNO}_{3} / \mathrm{HF} / \mathrm{H}_{2} \mathrm{O}$ mixture chemical solution in a ratio of $4: 34: 162$ (volume) at $25^{\circ} \mathrm{C}$ for $1.5 \mathrm{~min}$. The current density ranged from 0 to $-1 \mathrm{~V}$ in the saturation current density region. Since heavy doping under contacts keeps minority carriers away from high recombination front contact, the saturation current density of the $2.5 \mathrm{hr}$ sample is higher than that of the $3 \mathrm{hr}$ sample. Thus, the open-circuit voltage of the $2.5 \mathrm{hr}$ sample is smaller than that of the $3 \mathrm{hr}$ sample as shown in Figure 8 due to larger saturation current density of the $2.5 \mathrm{hr}$ sample. Therefore, based on the results of Figure 8, diffusion was carried out at $950^{\circ} \mathrm{C}$ for $3 \mathrm{hrs}$ to examine the effects of SNW array length on the photovoltaic characteristics of RJSNW solar cells.

Figure 9 plots $J-V$ curves of illuminated (AM 1.5) RJSNW solar cells with lengths of 600, 900, and $10000 \mathrm{~nm}$. All SNW/p-Si(100) structures were formed by the diffusion of phosphorus at $950^{\circ} \mathrm{C}$ for 3 hrs. The experimental results indicate that the CEs of RJSNW solar cells decreased as the lengths of the SNW arrays increased. A p/n junction solar cell between fully n-type SNWs and the p-type substrate has been demonstrated [22]. Although compared to [22] this work has so far advanced the efficiencies, further optimization is still needed for the future development of RJSNW solar cells. Theoretical studies have indicated 


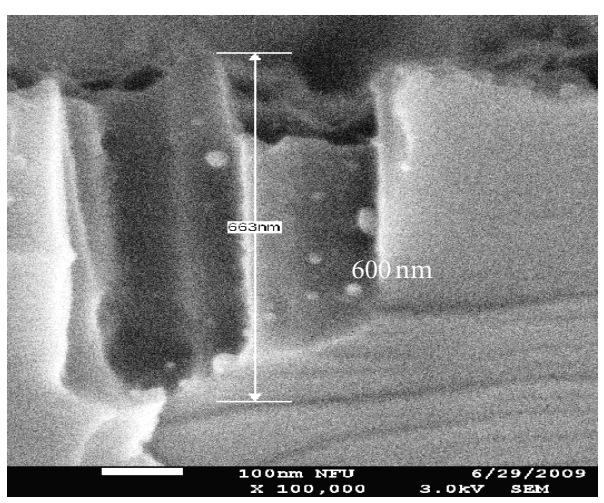

(a)

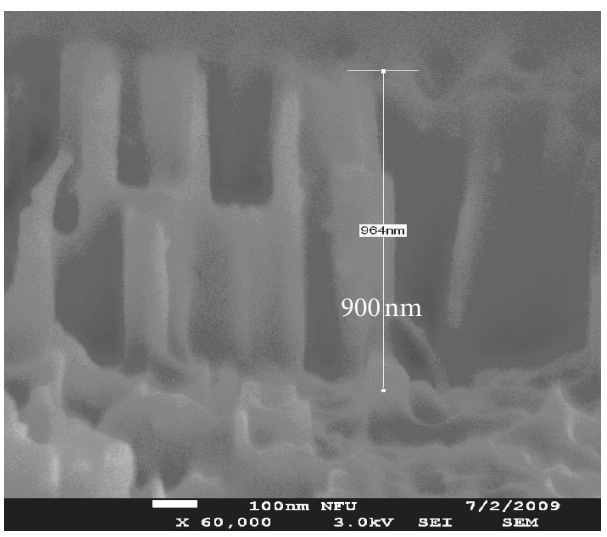

(c)

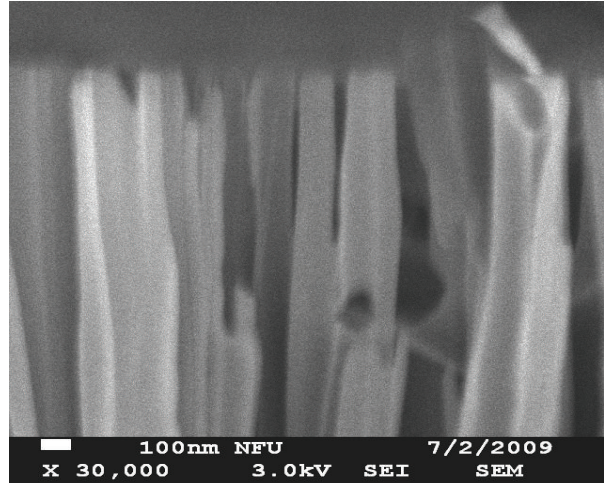

(b)

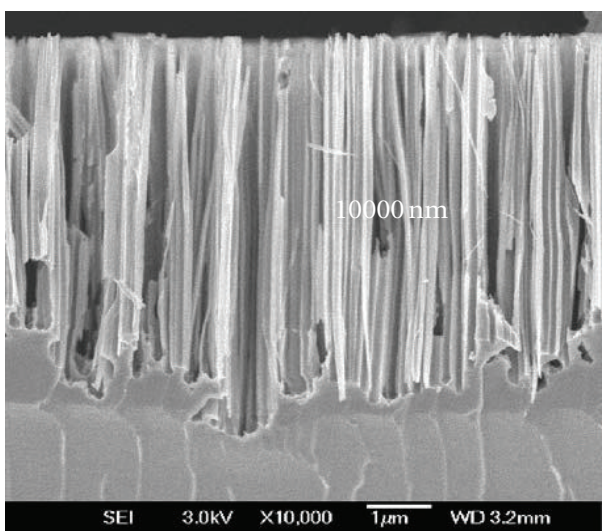

(d)

FIgURE 4: SEM images of various SNW/p-Si(100) structures. Etching conditions were aqueous $\mathrm{AgNO}_{3} / \mathrm{HF} / \mathrm{H}_{2} \mathrm{O}$ mixture chemical solution in a ratio of $4: 34: 162$ (volume) at $25^{\circ} \mathrm{C}$ for (a) 1.5 , (b) 1.5 (enlargement of (a)), (c) 3, and (d) 30 min. The concentration of $\mathrm{AgNO}_{3}$ was $1 \mathrm{~mol} \mathrm{~L}^{-1}$. Lengths of SNW arrays were 600,900 , and $10000 \mathrm{~nm}$, respectively.

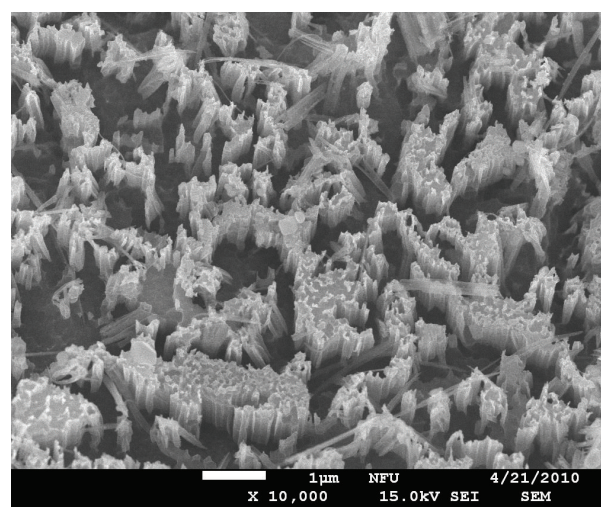

(a)

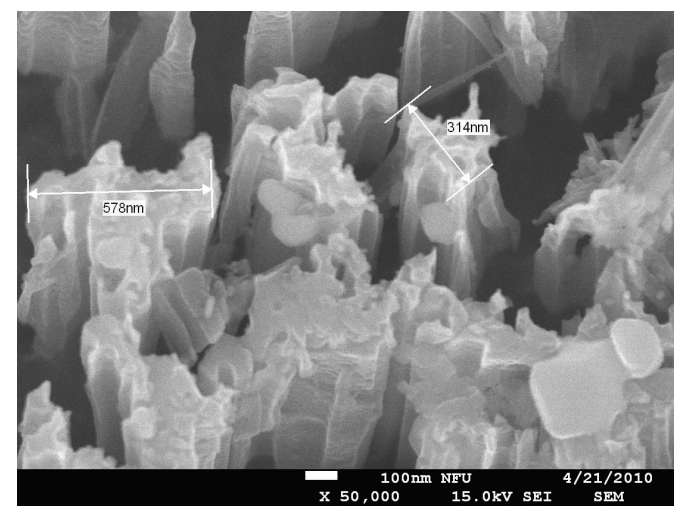

(b)

FIGURE 5: Top morphologies of SNW/p-Si(100) structure, magnified at (a) $\times 10 \mathrm{k}$, and (b) $\times 50 \mathrm{k}$. Etching conditions were aqueous $\mathrm{AgNO}_{3} / \mathrm{HF} / \mathrm{H}_{2} \mathrm{O}$ mixed chemical solution in a ratio of $4: 34: 162$ (volume) at $25^{\circ} \mathrm{C}$ for $3 \mathrm{~min}$. Cross-sections of SNW arrays had non-regular morphologies and sizes from 300 to $1000 \mathrm{~nm}$.

that coaxial SNW structures have better carrier collection and improved efficiency [5]. Additionally, in the solar cell wavelength range of interest, the longest SNW arrays have the lowest reflectance, as shown in Figure 6. Therefore, the CEs of long RJSNW solar cells should exceed those of short cells, but the opposite result was obtained. To study this phenomenon, Figure 10 presents an SEM image of an $\mathrm{Al} / \mathrm{Ti} / \mathrm{RJSNW} / \mathrm{p}-\mathrm{Si}(100)$ stacked structure with a length of $10000 \mathrm{~nm}$. It can be seen that the electrode cannot be filled in all surfaces of long RJSNW arrays. Therefore, the carriers that 


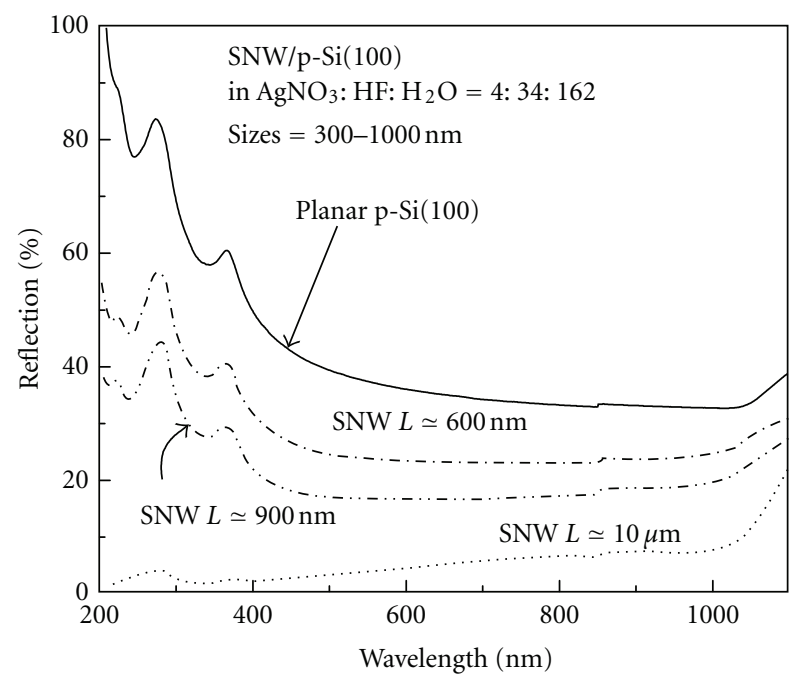

FIGURE 6: Reflectance spectra of various SNW/p-Si(100) structures with SNW lengths of 600, 900, and $10000 \mathrm{~nm}$. Etching conditions were aqueous $\mathrm{AgNO}_{3} / \mathrm{HF} / \mathrm{H}_{2} \mathrm{O}$ mixture chemical solution in a ratio of $4: 34: 162$ (volume) at $25^{\circ} \mathrm{C}$ for (a) 1.5 , (b) 3 , and (c) $30 \mathrm{~min}$. Reflectance spectrum of p-type planar $\mathrm{Si}(100)$ wafer is shown as reference. An integrating sphere was used to ensure that all reflected light was captured over all angles. The diameter of integrating sphere is $60 \mathrm{~mm}$.



FIgUre 7: Profile of phosphorus concentration in RJSNW/p-type $\mathrm{Si}(100)$ solar cell, determined by secondary ion mass spectroscopy (SIMS). SNW/p-type $\mathrm{Si}(100)$ structures were formed by diffusion of phosphorus at $950^{\circ} \mathrm{C}$ for $3 \mathrm{hrs}$.

are generated by incoming light cannot be rapidly collected within a short diffusion length. $J-V$ measurements indicated that the sample with a length of $600 \mathrm{~nm}$ was approximately one-tenth as resistive as that with a length of $10 \mu \mathrm{m}$, as shown in Figure 11, where the contact resistance,

$$
R_{C}=\left(\frac{\partial J}{\partial V}\right)_{V=0}^{-1},
$$

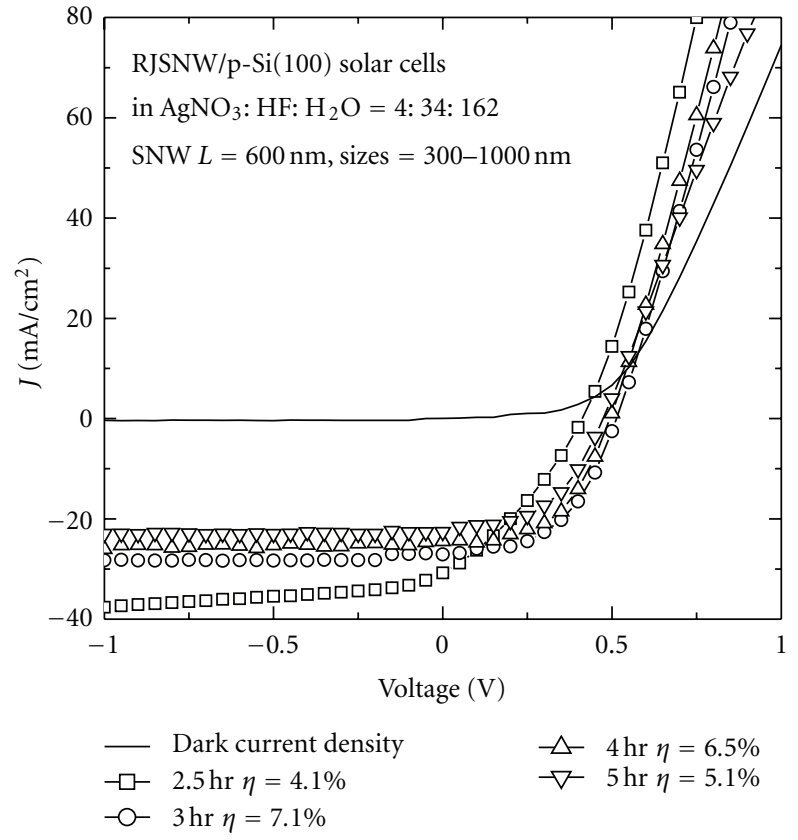

FIGURE 8: Current density-voltage $(J-V)$ curves of various dark and illuminated (AM 1.5) RJSNW solar cells. Etching conditions were aqueous $\mathrm{AgNO}_{3} / \mathrm{HF} / \mathrm{H}_{2} \mathrm{O}$ mixture chemical solution in a ratio of $4: 34: 162$ (volume) at $25^{\circ} \mathrm{C}$ for (a) 1.5 , (b) 3, and (c) $30 \mathrm{~min}$. Lengths and cross-section sizes of SNW arrays were $600 \mathrm{~nm}$ and 300-1000 nm, respectively. SNW/p-type Si(100) structures were formed by diffusion of phosphorus at $950^{\circ} \mathrm{C}$ for $2.5,3,4$, and $5 \mathrm{hrs}$, respectively.

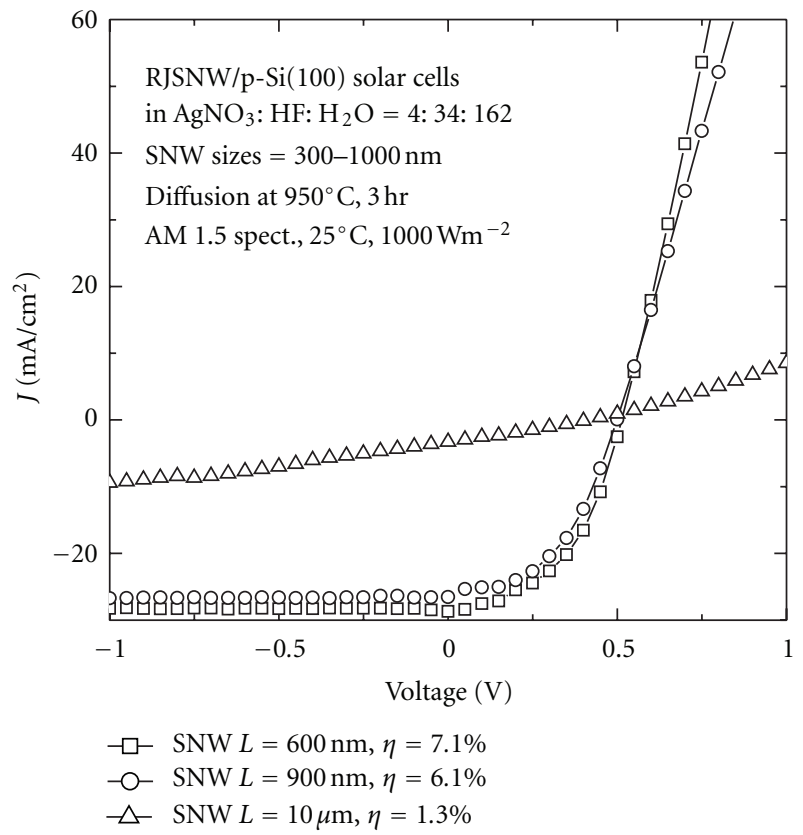

FIGURE 9: $J-V$ curves of various illuminated (AM 1.5) n-type SNW/p-Si(100) solar cells with SNW array lengths of 600, 900, and $10000 \mathrm{~nm}$. Etching conditions were aqueous $\mathrm{AgNO}_{3} / \mathrm{HF} / \mathrm{H}_{2} \mathrm{O}$ mixture chemical solution in a ratio of $4: 34: 162$ (volume) at $25^{\circ} \mathrm{C}$ for (a) 1.5, (b) 3, and (c) $30 \mathrm{~min}$. All SNW/p-Si(100) structures were formed by diffusion of phosphorus at $950^{\circ} \mathrm{C}$ for $3 \mathrm{hrs}$. 


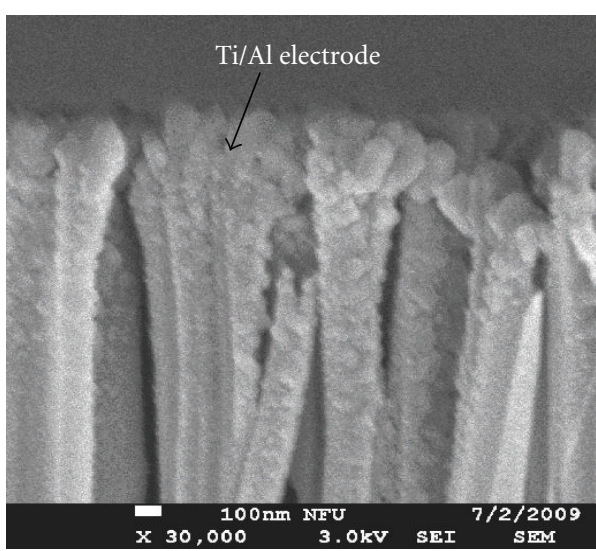

FIGURE 10: SEM image of Al/Ti/RJSNWp-Si(100) stacked structure with length of $10000 \mathrm{~nm}$ sample. Etching conditions were aqueous $\mathrm{AgNO}_{3} / \mathrm{HF} / \mathrm{H}_{2} \mathrm{O}$ mixed chemical solution in a ratio of $4: 34: 162$ (volume) at $25^{\circ} \mathrm{C}$ for $30 \mathrm{~min}$.

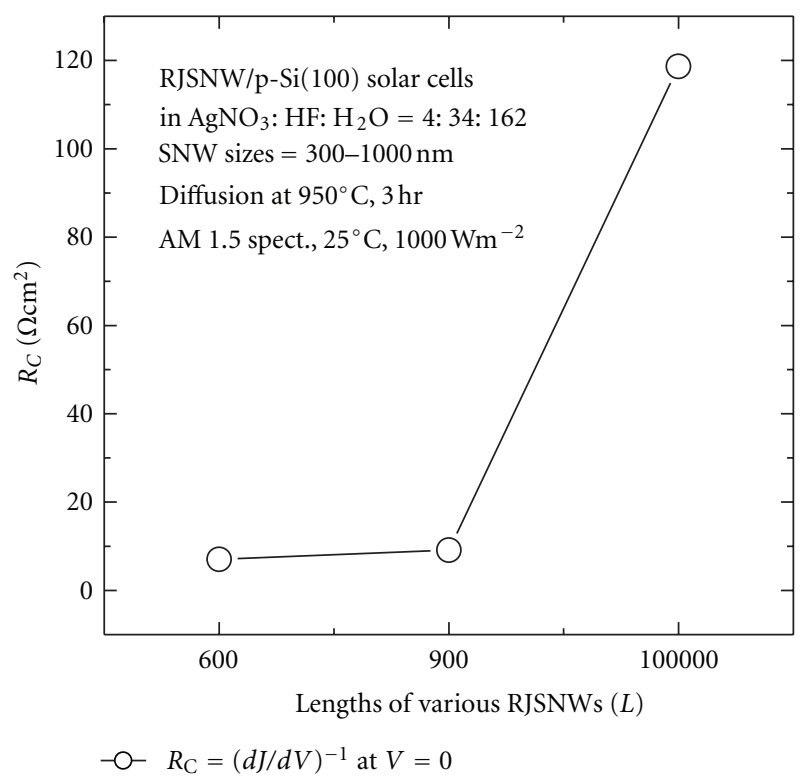

Figure 11: Contact resistances of RJSNWs of lengths 600, 900, and $10000 \mathrm{~nm}$. Etching conditions were aqueous $\mathrm{AgNO}_{3} / \mathrm{HF} / \mathrm{H}_{2} \mathrm{O}$ mixture chemical solution in a ratio of $4: 34: 162$ (volume) at $25^{\circ} \mathrm{C}$ for (a) 1.5, (b) 3 , and (c) $30 \mathrm{~min}$.

is estimated from the $J-V$ curve at $V=0$. The fact that the contact resistance of shorter RJSNWs is lower is attributed to the coalescence of the $\mathrm{Al}$ film into a vertical RJSNW and the enhanced interaction with its surface. Another possible reason is the significantly enhanced carrier travel path length before collection by the front electrode because of the greatly increased junction area due to the unique nanowire $3 \mathrm{D}$ morphology, if compared to a planar structure. Therefore, the improvement in the electrode/RJSNW contact dominates the collection of carriers in coaxial core-shell-type SNW array solar cells and thus supports the implementation of a new contact in the RJSNW solar cells.



FIgURE 12: External quantum efficiencies (EQEs) of various RJSNW solar cells, measured for incident light with wavelengths of $350 \sim 1100 \mathrm{~nm}$. Etching conditions were aqueous $\mathrm{AgNO}_{3} / \mathrm{HF} / \mathrm{H}_{2} \mathrm{O}$ mixture chemical solution in a ratio of $4: 34: 162$ (volume) at $25^{\circ} \mathrm{C}$ for (a) 1.5, (b) 3, and (c) $30 \mathrm{~min}$.

To understand the mechanism of improvement, the external quantum efficiencies (EQEs) of various RJSNW solar cells were measured for incident light with wavelengths of 350 1100 nm, as shown in Figure 12. The reduced EQE in low and long wavelengths is well known to be associated with recombination at the front and rear surfaces. At medium wavelengths, reflection and a low carrier diffusion length reduce overall QE. A shorter SNW solar cell has a larger EQE, implying that the origin of the increase is related to effective carrier conduction away from the $\mathrm{p} / \mathrm{n}$ junction, associated with a short electrode/RJSNW contact. The photovoltaic property of the RJSNW solar cell with a maximum EQE value of $\sim 64.6 \%$ at $700 \mathrm{~nm}$ was measured.

\section{Conclusions}

The photovoltaic characteristics of radial junction silicon nanowire (RJSNW) solar cells were demonstrated by the wet chemical etching of a p-type $\mathrm{Si}(100)$ wafer. An improved conversion efficiency of approximately $7.1 \%$ with a $J_{\text {sc }}$ of $27 \mathrm{~mA} / \mathrm{cm}^{2}$, a $V_{\text {oc }}$ of $500 \mathrm{mV}$, and an FF of $52 \%$ was obtained for an RJSNW array solar cell sample with a diffusion time of 3 hrs. Etching conditions were aqueous $\mathrm{AgNO}_{3} / \mathrm{HF} / \mathrm{H}_{2} \mathrm{O}$ mixture chemical solution in a ratio of $4: 34: 162$ (volume) at $25^{\circ} \mathrm{C}$ for $1.5 \mathrm{~min}$. Experimental results reveal that this RJSNW solar cell is a promising candidate for the development of nanostructured solar cells. 


\section{Acknowledgments}

The authors would like to thank the National Science Council of the Republic of China for the financial support under Contract nos. NSC 100-2221-E-150-087 and NSC 100-2622-E150-027-CC3. Technical support from National Nano Device Laboratories (NDL) of the Taiwan and Common Laboratories for Micro/Nano Science and Technology of National Formosa University is also acknowledged.

\section{References}

[1] C. L. Cheng, C. W. Liu, J. T. Jeng, B. T. Dai, and Y. H. Lee, "Fabrication and characterizations of black hybrid silicon nanomaterials as light-trapping textures for silicon solar cells," Journal of the Electrochemical Society, vol. 156, no. 5, pp. H356H360, 2009.

[2] B. M. Kayes, M. A. Filler, M. C. Putnam, M. D. Kelzenberg, N. S. Lewis, and H. A. Atwater, "Growth of vertically aligned Si wire arrays over large areas $\left(>1 \mathrm{~cm}^{2}\right)$ with $\mathrm{Au}$ and $\mathrm{Cu}$ catalysts," Applied Physics Letters, vol. 91, no. 10, Article ID 103110, 2007.

[3] J. Kim, J. H. Yun, C. S. Han, Y. J. Cho, J. Park, and Y. C. Park, "Multiple silicon nanowires-embedded Schottky solar cell," Applied Physics Letters, vol. 95, no. 14, Article ID 143112, 2009.

[4] T. Stelzner, M. Pietsch, G. Andrä, F. Falk, E. Ose, and S. Christiansen, "Silicon nanowire-based solar cells," Nanotechnology, vol. 19, no. 29, Article ID 295203, 2008.

[5] L. Tsakalakos, J. Balch, J. Fronheiser, B. A. Korevaar, O. Sulima, and J. Rand, "Silicon nanowire solar cells," Applied Physics Letters, vol. 91, no. 23, Article ID 233117, 2007.

[6] B. Tian, X. Zheng, T. J. Kempa et al., "Coaxial silicon nanowires as solar cells and nanoelectronic power sources," Nature, vol. 449, no. 7164, pp. 885-889, 2007.

[7] E. C. Garnett and P. Yang, "Silicon nanowire radial p-n junction solar cells," Journal of the American Chemical Society, vol. 130, no. 29, pp. 9224-9225, 2008.

[8] J. Y. Yang, C. W. Liu, C. L. Cheng et al., "Photovoltaic characterizations of crisscrossed-silicon-nanorod solar cells," IEEE Electron Device Letters, vol. 30, no. 12, pp. 1299-1301, 2009.

[9] M. Bettge, S. MacLaren, S. Burdin et al., "Low-temperature vapour-liquid-solid (VLS) growth of vertically aligned silicon oxide nanowires using concurrent ion bombardment," Nanotechnology, vol. 20, no. 11, Article ID 115607, 2009.

[10] A. P. Goodey, S. M. Eichfeld, K. K. Lew, J. M. Redwing, and T. E. Mallouk, "Silicon nanowire array photoelectrochemical cells," Journal of the American Chemical Society, vol. 129, no. 41, pp. 12344-12345, 2007.

[11] J. R. Maiolo, B. M. Kayes, M. A. Filler et al., "High aspect ratio silicon wire array photoelectrochemical cells," Journal of the American Chemical Society, vol. 129, no. 41, pp. 12346-12347, 2007.

[12] H. Fang, X. Li, S. Song, Y. Xu, and J. Zhu, "Fabrication of slantingly-aligned silicon nanowire arrays for solar cell applications," Nanotechnology, vol. 19, no. 25, Article ID 255703, 2008.

[13] A. Kandala, T. Betti, and A. F. I Morral, "General theoretical considerations on nanowire solar cell designs," Physica Status Solidi A, vol. 206, no. 1, pp. 173-178, 2009.

[14] B. M. Kayes, H. A. Atwater, and N. S. Lewis, "Comparison of the device physics principles of planar and radial $p-n$ junction nanorod solar cells," Journal of Applied Physics, vol. 97, no. 11, Article ID 114302, 2005.

[15] I. Ponomareva, M. Menon, E. Richter, and A. N. Andriotis, "Structural stability, electronic properties, and quantum conductivity of small-diameter silicon nanowires," Physical Review B, vol. 74, no. 12, Article ID 125311, 2006.

[16] A. J. Read, R. J. Needs, K. J. Nash, L. T. Canham, P. D. J. Calcott, and A. Qteish, "First-principles calculations of the electronic properties of silicon quantum wires," Physical Review Letters, vol. 69, no. 8, pp. 1232-1235, 1992.

[17] K. Q. Peng, X. Wang, and S. T. Lee, "Silicon nanowire array photoelectrochemical solar cells," Applied Physics Letters, vol. 92, no. 16, Article ID 163103, 2008.

[18] V. Sivakov, G. Andrä, A. Gawlik et al., "Silicon nanowire-based solar cells on glass: synthesis, optical properties, and cell parameters," Nano Letters, vol. 9, no. 4, pp. 1549-1554, 2009.

[19] Z. Huang, T. Shimizu, S. Senz, Z. Zhang, N. Geyer, and U. Gösele, "Oxidation rate effect on the direction of metalassisted chemical and electrochemical etching of silicon," Journal of Physical Chemistry C, vol. 114, no. 24, pp. 10683-10690, 2010.

[20] Z. P. Huang, T. Shimizu, S. Senz et al., "Ordered arrays of vertically aligned [110] silicon nanowires by suppressing the crystallographically preferred $<100\rangle$ etching directions," Nano Letters, vol. 9, no. 7, pp. 2519-2525, 2009.

[21] K. Q. Peng, H. Fang, J. J. Hu et al., "Metal-particle-induced, highly localized site-specific etching of Si and formation of single-crystalline Si nanowires in aqueous fluoride solution," Chemistry, vol. 12, no. 30, pp. 7942-7947, 2006.

[22] K. Q. Peng, Y. Xu, Y. Wu, Y. Yan, S. T. Lee, and J. Zhu, “Aligned single-crystalline Si nanowire arrays for photovoltaic applications," Small, vol. 1, no. 11, pp. 1062-1067, 2005.

[23] K. Q. Peng, J. Hu, Y. Yan et al., "Fabrication of single-crystalline silicon nanowires by scratching a silicon surface with catalytic metal particles," Advanced Functional Materials, vol. 16, no. 3, pp. 387-394, 2006.

[24] V. Y. Yerokhov, R. Hezel, M. Lipinski et al., "Cost-effective methods of texturing for silicon solar cells," Solar Energy Materials and Solar Cells, vol. 72, no. 1-4, pp. 291-298, 2002.

[25] S. M. Sze, Semiconductor Devices: Physics and Technology, Wiley, New York, NY, USA, 1985. 




International Journal of

Medicinal Chemistry

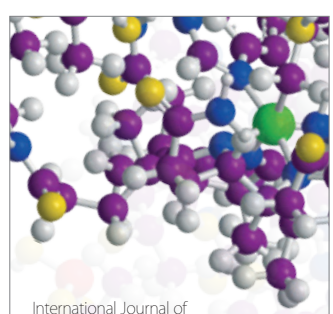

Carbohydrate Chemistry

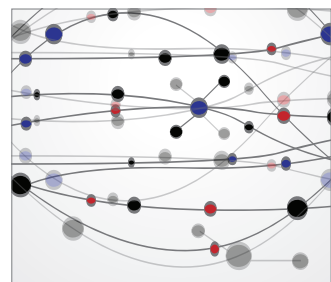

The Scientific World Journal
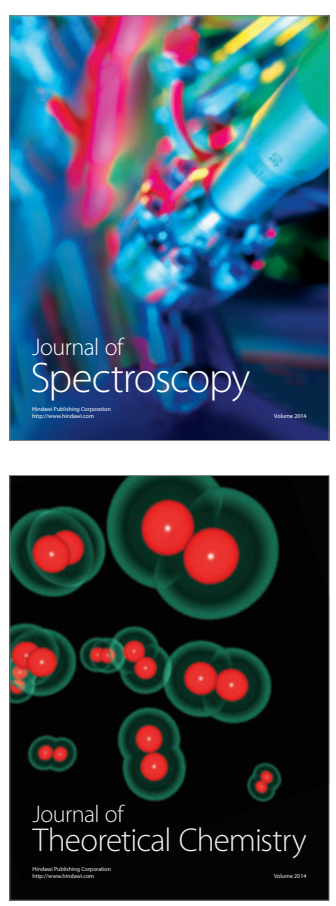


Submit your manuscripts at

http://www.hindawi.com
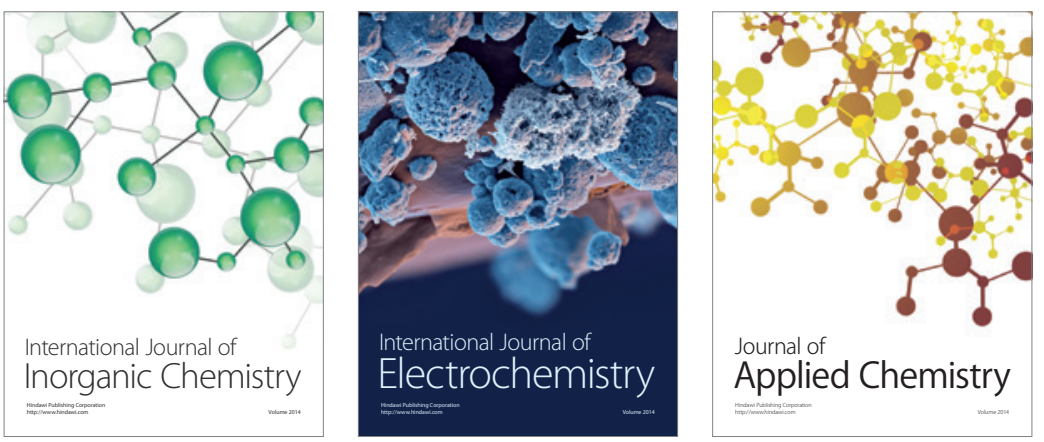

Journal of

Applied Chemistry

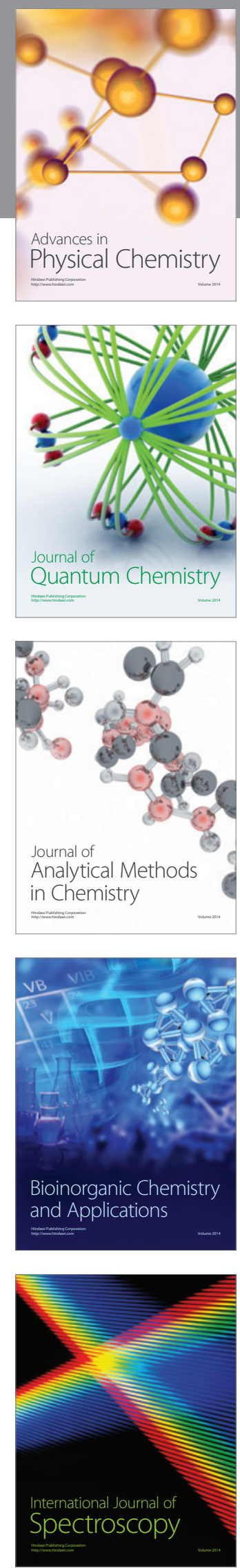